\title{
Green Energy towards Sustainability from the Islamic Perspective
}

\section{Nur Hidayah Abdul Jabar ${ }^{\mathrm{a}, \mathrm{b}}$, Zul Ilham ${ }^{\mathrm{a,c} *}$, Shaikh Mohd Saifuddeen ${ }^{\text {b,d }}$, Noor Naemah Abdul Rahman ${ }^{b}$}

\author{
${ }^{a}$ Institute of Biological Sciences, Faculty of Science, University of \\ Malaya 50603 Kuala Lumpur, Malaysia \\ ${ }^{b}$ Academy of Islamic Studies, University of Malaya 50603 Kuala \\ Lumpur, Malaysia
}

${ }^{c}$ UM Sustainable Development Solutions Network (UM-SDSN), Level 6, Research Management and Innovation Complex, , University of Malaya 50603 Kuala Lumpur, Malaysia

${ }^{d}$ Center for Science and Environment Studies, Institute of Islamic Understanding Malaysia, 2, Langgak Tunku, Off Jalan Duta, 50480 Kuala Lumpur, Malaysia

Received: July 2, 2015/ Accepted: December 22, 2015

\begin{abstract}
Sustainable development is a concept mooted to ensure that the needs of the present are met without compromising the needs of the future. Islam has outlined a number of concepts for ensuring that the environment is managed in a responsible and sustainable manner. These concepts are wisdom (hikmah), justice ('adl), public interest (maslahah) and innovation (ijtihad). The framework of higher purposes of Islamic Divine law or maqasid al-shariah also provides guidance by highlighting five objectives (viz. faith, life, intellect, progeny and property) that need to be protected in carrying out development. However, the challenge lies in putting these concepts and approaches into practice. While there is a good theoretical understanding of these Islamic concepts and approaches, the reality is that many still do not practice what they know in their individual daily lives as well as in policy formulation. Environmental issues including green energy production should not be dismissed simply as a worldly affair. As such, it is imperative for Muslims to not only be aware of these issues, but also to put sustainability into practice in order to achieve the "good life" concept or hayattayibbah.
\end{abstract}

Keywords: Environmental ethics, Sustainable development, Islam

\section{Introduction}

The world continues to develop at a rapid pace creating an unavoidable high demand of energy consumption. The availability of sufficient energy is one of the catalysts needed for development. The concern now is on solving the question of how to sustain energy availability for the future. The reality is that the main sources of energy supply are from non-renewable energy sources such as natural gases, petroleum, and coal.

\footnotetext{
Corresponding Author
}

Tel.:+603-79674014 ; Fax: +603-79674178 ; E-mail: ilham@um.edu.my
Based on a report by the International Environmental Agency (IEA), $80 \%$ of current energy consumption is obtained from fossil fuels with petroleum being the main energy provider $(32.8 \%)$, followed by coal (27.2\%) and natural gas (20.9\%) [1]. Only a small amount of energy consumed is from alternative sources such as solar, hydroelectric, geothermal, wave, biomass, nuclear and other non-renewable energy. It is reported that until the year 2011, the consumption of energy from these alternative energy sources was lower than $10 \%$ of the total [2].

The depletion of non-renewable energy sources poses a potential problem for energy security especially for future generations. Will future generations be able to obtain the same energy sources that we have now? This, coupled with the increasing price of fossil fuels, threatens the economic sustainability of the current generation and hence, poses a potential energy crisis for future generations. The dependence on energy consumption to meet human needs and activities is inevitable. In view of this critical scenario, there is an urgent need for wider utilization of alternative energy sources to replace the dependency on non-renewable energy sources before they run out.

One of the viable alternatives is green energy. The need for green energy is becoming increasingly important not just because of the depletion of fossil fuel resources but also for environmental sustainability. Fossil fuel combustion is known to significantly affect the environment, and is the major contributor of carbon dioxide emissions that comprises more than $60 \%$ of the total greenhouse gases worldwide, resulting in climate change [3]. Greenhouse gases are responsible for the increase of the world's temperature and environmental changes to the land, atmosphere and ocean. Their presence in the atmosphere takes several years to disappear resulting in global warming which not only affects the present but also future generations [4].

In this study, the interrelation between green energy for sustainability is being discussed from a non-conventional Islamic viewpoint, where maqasid al-shariah plays an important role.

\section{Green Energy and the Need for Sustainability}

The definition of "green energy" evolves in time, rendering it difficult to be given a precise definition. Green energy is regarded to be environmentally-friendly because it results in less pollution to the environment compared with fossil fuels. The term "green energy" is also now used to differentiate between less polluting energy and the dominant fossil fuels that cause greater pollution to the environment. The term can also be applied to an energy system that potentially has low harmful effects to the environment [5]. In other words, green energy is about "a man doing his business without changing much in the environment" [6]. In general, green energy is generated from renewable energy sources such as sunlight, hydroelectric, ocean, wind, geothermal heat and tidal waves. Green energy is also categorized as renewable energy because the energy sources can be replenished naturally.

The exploitation, scarcity and excessive utilization of natural resources are the main reasons that have led to the increase in awareness of the concept of "sustainable development" [7]. The relationship between the use of green energy and sustainable development is clearly shown in the way that green energy can reduce environmental pollution and provide energy security to the world's population.

Sustainable development demands pollution-free technology and energy resources, even though in reality, there is no energy source that is entirely free from affecting the environment. 
Nonetheless, the use of green energy is still the best option to replace the current conventional energy and minimize dependency on fossil fuels.

We are now experiencing climate change at the global scale. While this is inevitable, efforts can be taken to slow down this process through gradual substitution of fossil fuels with green energy. As consumers of fossil fuels, mankind is the biggest contributor to greenhouse gas emissions through our daily activities, such as the use of automobiles, machines, electricity, chemicals and pesticides.

A large area is required to generate green energy, for instance hydroelectric dams and solar harvesting plants. The availability of resources would also require the relocation of industry to make the acquisition of energy possible. Sustainable energy gives a high expectation that renewable resources can substitute for conventional energy, but the real question is how much energy can be supplied by the renewable resources? This question is even more important when we consider the ever-increasing population of mankind. These are some of the challenges that need to be addressed in order to utilize green energy.

\section{Sustainable Development: an Islamic Perspective}

No doubt, there exist challenges in utilizing green energy. Yet, it is also apparent that green energy is the most viable alternative to fossil fuels, and would assist in realizing the concept of sustainable development. The concept of sustainable development has gone evolved over the years [8]. One widely-accepted definition of "sustainable development' was introduced in 1987 published in the United Nation's document popularly known as the "Brundtland Report" in which "sustainable development" is defined as the use of resources that "meets the needs of the present without compromising the ability of future generations to meet their own needs." [9].

In making green energy as a practical agenda for sustainable development, three conditions should be met [10]. The first is that the use of green energy cannot exceed the time taken for the resources to be renewed. The second condition is that the use of non-renewable energy must be replaced by other alternative resources before it runs out. Finally, there is a need to maintain the processes and structure of the ecological system [11].

From the perspective of Islam, "sustainability" was defined by Al-Jayyousi as hayattayyibah which means "a good life," in which four key Islamic concepts associated with sustainable development are identified, namely wisdom (hikmah), justice ('adl), public interest (maslahah) and innovation (ijtihad) [8]. In addition, mankind is seen to be on earth as vicegerents or stewards (khalifah). The world contains all the materials for mankind to utilise, but the development must be sustainable and not cause massive destruction. This is one of the key points in the Islamic sustainability approach, in comparison to the secular one.

From these four basic concepts, Al-Jayoussi went on to elaborate that these concepts can be paired to result in other concepts relevant to sustainable development. When wisdom combines with innovation, this will result in excellence (ihsan). When justice combines with wisdom, this will result in the manifestation of the glorification of God (tasbih). When justice combines with public interest, this will result in a balanced approach (mizan). When public interest combines with innovation, this will result in mercy (arham). The emphasis of these concepts is to achieve the aims of sustainable development, i.e. to revive and enable the earth to prosper, to interact with the environment in a just way using the best approach, and to prevent the environment from any destruction [12].
The environment should not be regarded as a non-living entity, but a living entity that is invaluable to all the creatures on the earth. Therefore, it is the responsibility of mankind as stewards of this planet to take care of the environment and all its resources in the best possible manner.

Islam views that the relationship between mankind and the environment should not be lopsided. One cannot dominate the other. In fact, Islam stresses the need for a harmonious interaction between mankind and the environment. Mankind is given the freedom to utilize natural resources in the environment in order to create prosperity. However, this freedom must be coupled with wisdom in order to avoid destruction. This wisdom is important in order to preserve and sustain the environment and all its components.

This is in line with the concept of trust (amanah) which aims to manage the environment and create peace, law and order in terms of environmental preservation. When the environment is managed in a trustworthy manner, this would result in balance between man and the environment. It is the obligation of mankind to maintain the balance of the Earth created by God. Overdependence on, and overutilization of, fossil fuels has upset the balance of the world's climate resulting in global warming. The Quran stressed in a famous and oft-quoted verse that environmental damage is caused by humans' own misdeeds [13].

\section{Relating Sustainable Development to Maqasid al-shariah}

When it comes to implementing concepts into actions, it has been argued that maqasid al-shariah or the higher purposes of Islamic divine law, provide the most suitable guidance for Muslims to adopt [14]. Sustainable development and the utilization of green energy can be discussed by using this framework which focuses on the protection of the faith, life, intellect, progeny and property [15].

It is compulsory for Muslims to conserve the environment as this is akin to protecting faith in God. The sin of causing destruction to the environment results in imbalance and disharmony, and hence affects a harmonious relationship between Muslims and God. The environment is created by God as a sign of trust in mankind. As such, it is the Muslim's view that protecting the environment contributes towards the protection of the faith which is the first objective of maqasid al-shariah.

This in turn relates to the second objective of maqasid alshariah which is to protect life. In order to ensure that mankind continues to survive, it is imperative that the environment is protected. This is because mankind is part and parcel of the environment. All actions that result in the destruction of the environment clearly threaten human life. The use of fossil fuels is now known to be the major culprit for greenhouse gases. The emission of greenhouse gases in the atmosphere results in global warming that leads to a lot of environmental disasters such as the melting of polar ice caps, rising sea levels, drastic change in the world's climate as well as severe change in the ecosystem. This would certainly pose danger to the collective life of mankind.

The third objective of maqasid al-shariah is the protection of the intellect. Islam views life in this world in a holistic manner in which several aspects are given attention. These aspects include the physical, the mental and the spiritual. The spiritual aspect is addressed by the first objective of maqasid al-shariah. This third objective, i.e. protection of the intellect, addresses the mental aspect. The environment provides mankind with a great capacity as a place for mankind to learn. The environment becomes an important avenue for mankind to enhance his knowledge and intellect by observing his surroundings. The environment is also a tool for the development of human civilization, which can only be 
achieved if mankind uses his intellect to the best of his capacity. The inability to utilize the intellect in the best possible way would pose a threat to the survival of mankind.

When life is threatened as the result of environmental problems, this would pose a risk to the fourth objective of maqasid al-shariah, namely to protect lineage. Protecting the lineage in accordance to Divine Islamic law is to sustain the life of future generations. If we go back to the definition of sustainable development in the Brundtland Report, the use of resources that "meet the needs of the present without compromising the ability of future generations to meet their own needs" [9] is definitely in line with the fourth objective of maqasid al-shariah in ensuring the survival of future generations.

The fifth objective of maqasid al-shariah is the protection of property. The natural resources found in the environment are considered as property that needs to be managed wisely and sustainably. Everything that is created by God on this world is for the benefit of mankind. However, blatant exploitation of natural resources often results in catastrophic disasters, such as landslides, water pollution, soil erosion and flash floods. If viewed as a property, the value of natural resources is priceless, and once it is depleted or used, it is almost impossible to replace or retrieve them [16]. This is one reason why sustainable development is important, and also the rationale why green energy is a more viable option for mankind.

\section{Challenges in Putting the Concepts Into Action}

It is easy to list down concepts or philosophical approaches when it comes to issues such as sustainable development. All the concepts and frameworks are well and nicely documented, but then the question is, what comes next?

In an exploratory study conducted at the University of Malaya in Kuala Lumpur, Malaysia, involving students at the university, it was found that $55 \%$ of the respondents have a good understanding on the Islamic concepts related to the environment and sustainable development [17]. The study, for example, found that there is a positive correlation between understanding of Islamic concepts and awareness towards the importance of green energy. However, the study also found that while respondents have a good understanding on the Islamic concepts, the implementation of these concepts into policy formulation and practice is very much lacking.

This may be due to several factors such as a contented lifestyle, lack of facilities to encourage green energy utilisation, and lack of enforcement. It is harder to "walk the talk" regarding green energy and sustainable development because there is a mainstream perception that green is always expensive and boring. This is somewhat true, because green energy practices convince people to use expensive LED bulbs and switch off every electrical outlet whenever unused. For many people, this is indeed a challenging adjustment to make.

It is definitely much easier to preach than to practice. It is even a greater sin to simply preach when there is no intention to practice what is preached [18]. The will to change and adjust has to start from an early age. Children must be exposed to green practices, and religious education should also incorporate information about the importance of practicing sustainability. It is crucial that Muslims do not view environmental issues and sustainable development as merely worldly issues that are of little concern. Muslims must realize that unless proactive and positive actions are taken, the deterioration of the environmental condition would also affect them in the long run, if not now.

\section{Concluding Remarks}

Islam does not oppose development. That being said, development must be carried out in line with the framework outlined through the higher purposes of Islamic divine law (maqasid al-shariah). This is to ensure that development that is carried out does not pose any risk to mankind and the environment. The true challenge, however, is to translate Islamic concepts and philosophical approaches into practice. To do this, Muslims have to change their mindset and view the issue of sustainable development to be a part of their task as stewards as set forth by God. It is about time that the Muslim community plays an important role in the global arena of sustainable development, especially with the recently launched Sustainable Development Goals (SDGs). This realization would trigger an awareness to ensure that natural resources are managed responsibly, wisely and sustainably which would help to ensure that the needs of the present would be met without jeopardizing the needs of the future. If this could be realized, than the aim to achieve a good life (hayattayibbah) could be achieved.

\section{Acknowledgements}

The authors would like to thank University of Malaya (RUoo72014), Applied Sciences with Islamic Studies Program, and Sustainability Science Research Cluster for all the support received.

\section{References}

[1] International Energy Agency (IEA). Energy supply security 2014. Paris OECD/IEA; 2014.

[2] International Energy Agency (IEA). Tracking clean energy progress 2014. Paris: OECD/IEA; 2014.

[3] Hook M, Tang X. Depletion of fossil fuels and anthropogenic climate change - a review. Energy Policy 2013;52:797-809.

[4] United States Environmental Protection Agency. Climate change: action plan to address climate change, 2014 http://www.epa.gov/climatechange/. Accessed 20 February 2015.

[5] Li X. Green energy for sustainability and energy security. In: Li X, editor. Green energy: basic concepts and fundamentals, London: Springer; 2011, p. 1-16.

[6] Bejan A, Lorente S. Constructal theory and its relevance to green energy. Int J Green Energy 2007;4:105-117.

[7] Tuazon D, Corder GD, McLellan BC. Sustainable development: a review of theoretical contributions. Int J Sust Future Human Security 2013;1:40-48.

[8] Al-Jayoussi O. Islam and sustainable development: new worldviews. Surrey: Gower; 2012.

[9] United Nations (UN). Report of the world commission on environment and development. Oslo: UN; 1987.

[10] Mostert E. A framework for conflict resolution. Water Internationa 1998;23:206-215.

[11] Ostrom E. Sustainable social-ecological systems: an impossibility?, 2007.http://dlc.dlib.indiana.edu/archive/oooo2199/o1/Wo72_Ostrom_ DLC.pdf. Accessed 25 February 2015.

[12] Majeed ABA, Yang AB. Pengurusan bijak alam sekitar (In Malay). Kuala Lumpur: IKIM;200o. 
[13] Nakamura M, Siddique S, Bajunid OF. Islam and civil society in south east asia. Singapore:ISEAS;2001.

[14] Saifuddeen SM, Rahman NNA, Isa NM, Baharuddin A. Maqasid alshariah as a complementary framework to conventional bioethics. Sci Eng Ethics 2014;2:317-327.

[15] Saifuddeen SM, Wei CL, Ibrahim AH, Khotib NAM. Islamic ethical framework to tackle scientific and technological dilemmas. J Dharma 2013;38:373-386.

[16] Heinzerling L, Ackerman F. Pricing the priceless: cost-benfit analysis of environmental protection. Washington: Georgetown University;2002.

[17] Ilham Z. Unpublished research project report. University of Malaya;2014.

[18] Ogunbado AF, Al-Otaibi AM. Is quality management an Islamic value?. IOSR J Business Management 2013;8:6-13. 